\title{
Bio-efficacy of some Fungicides against Rice Blast (Pyricularia grisea) under Temperate Agro-climatic Conditions of Kashmir
}

\author{
Mohammad Najeeb Mughal*, Sabiya Bashir, N.A Sofi and Shabir Ahmed Wani \\ Mountain Research Centre for Field Crops, Sher-e-Kashmir University of Agricultural \\ Sciences and Technology of Kashmir 190025, India \\ *Corresponding author
}

\begin{tabular}{l} 
K e y w o r d s \\
$\begin{array}{l}\text { Evaluation, Rice } \\
\text { blast, Fungicides, } \\
\text { Pyricularia grisea, } \\
\text { Temperate agro- } \\
\text { climatic conditions, } \\
\text { Kashmir }\end{array}$ \\
\hline $\begin{array}{l}\text { Article Info } \\
\text { Accepted: } \\
\text { 26 June } 2018 \\
\text { Available Online: } \\
\text { 10 July } 2018\end{array}$ \\
\hline
\end{tabular}

A B S T R A C T

The bio-efficacy of seven popular fungicides viz., tricyclazole $45 \%+$ hexaconazole 10 WG, tricyclazole $18 \%+$ mancozeb $62 \%$, tricyclazole $75 \mathrm{WP}$, hexaconazole 5EC, mancozeb $75 \mathrm{WP}$, mancozeb $63 \% \mathrm{WP}+$ carbendazim $12 \% \mathrm{WP}$ and cabendazim $50 \mathrm{WP}$ were evaluated against rice blast (Pyricularia grisea) during kharif 2015 and 2016 under temperate agro-climatic conditions of Kashmir. Four foliar sprays of each fungicide at their recommended concentrations were separately applied. The first foliar spray of each fungicide was applied separately after appearance of disease, followed by two sprays at 10 to 15 days interval while last spay was applied at milk/dough stage of rice variety Kamad. Two years of experimentation revealed, that tricylazole $75 \mathrm{WP}$ was most efficacious in management of disease and resulted in mean disease incidence of 27.00 per cent, mean disease intensity of 11.63 per cent, neck blast incidence of 8.35 per cent and a grain yield of $36.50 \mathrm{qha}^{-1}$. Tricyclazole $45 \%+$ hexaconazole $10 \mathrm{WG}$ was next in efficacy with mean disease incidence, intensity and neck blast incidence of $32.41,14.34$ and 11.62 per cent and a grain yield $35.10 \mathrm{qha}^{-1}$, respectively. Tricyclazole $18 \%+$ mancozeb $62 \%$; mancozeb $63 \% \mathrm{WP}+$ carbendazim $12 \% \mathrm{WP}$; carbendazim $50 \mathrm{WP}$ and hexaconazole $5 \mathrm{EC}$ resulted in disease incidence of $35.62,36.937 .75$ and 47.79 per cent, mean disease intensity of 16.62 , $20.11,23.45$ and 29.06 per cent while mean neck blast incidence was $14.35,17.37,19.62$ and 21.80 per cent with a consequent grain yield of 34.00, 33.20, 32.75 and 30.20 qha $^{-1}$, respectively. Mancozeb 75 WP was found least efficacious and resulted in highest mean disease incidence, intensity, neck blast incidence and lowest grain yield of 56.12, 41.01 and 25.55 per cent and $28.25 \mathrm{qha}^{-1}$, respectively. However it was significantly superior than the untreated control where mean disease incidence, intensity, neck blast incidence and grain yield was $91.12,57.40$ and 35.55 per cent and $21.75 \mathrm{qha}^{-1}$, respectively.

\section{Introduction}

Rice (Oryza sativa L.) is the most important cereal crop of India. It is staple food crop of Jammu and Kashmir where it occupies 3.04 lakh hectare area with an annual production of 6466 thousand quintals. In Kashmir valley the area under rice cultivation is 1.43 lakh hectares and production is 3862 quintals with a productivity of 26.90 quintal per hectare 
(Anonymous, 2016). The crop is attacked by a number of fungal, bacterial and viral diseases, which inflict heavy yield losses every year. Among the fungal diseases, rice blast caused by Pyricularia grisea [Teliomorph: Magnaporthe grisea (Herbert) Barr.] brown leaf spot (Helminthosporium oryzae), rice sheath blight (Thanatephorus cucumeris), are important and potentially damaging in Jammu and Kashmir (Mohammad et. al., 2016). Due to mono-cropping, use of high yielding vulnerable genotypes and narrow genetic base coupled with high doses of nitrogenous fertilizers, the rice blast has turned to be a serious threat for stable rice production in Kashmir (Mohd et al., 2006). It has become a limiting factor in stable rice production especially for native popular rice varieties like Kamad, Mushkbudji, Zag, and other red rice varieties as huge losses are caused in production year after year. The pathogen attack the rice crop during all stages of its growth and symptoms can be seen on all above ground parts like leaves, nodes and neck of panicle. One of the major causes for the increased incidence of this disease has also been ascribed to the introduction and wide spread cultivation of high yielding fertilizers responsive varieties producing maximum number of productive tillers per unit area, thus creating conditions of increased relative humidity and prolonged leaf wetness and therefore, making the crop more vulnerable to the attack by the pathogen (Eizenga et al., 2002). Besides, native popular rice varieties lack gene(s) for blast resistance and therefore does not possess desirable levels of resistance and require support of frequent applications of fungicides. Therefore, an attempt was made to evaluate some systemic fungicides against the disease and the results are presented herein.

\section{Materials and Methods}

Thirty-days old seedlings of rice variety 'Kamad' were transplanted in $5 \times 2$ m plots in randomized block design replicating the treatments thrice during kharif 2015 and 2016 at Mountain Research Centre for field Crops, Khudwani, Kashmir. Four sprays of each systemic fungicide at their recommended concentrations were given separately at maximum appearance of disease, followed by 10 to 15 days intervals after first and second spray while fourth spray was applied at milk/dough stage of crop growth. Treatments where only water was sprayed served as check for all the experiments. Observations on disease incidence and intensity and neck blast incidence were recorded ten days after the last spray (Vihol et al., 2009), whereas the observation on grain yield were recorded at harvest and expressed in quintals per hectare.

The per cent disease incidence and intensity was recorded by using following formula;

Per cent disease incidence $=$

Number of diseased plants observed

$$
\underset{\text { Total number of diseased plants }}{\times 100}
$$

Per cent disease intensity

Sum of all the numerical rating

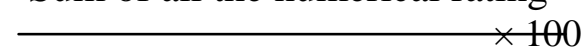

Number of hills observed $\times$ highest disease score

For calculating the disease ratings the scale given in table 1 was used.

\section{Results and Discussion}

\section{Field evaluation}

Persual of the two years data of (Table 1) revealed that tricylazole $75 \mathrm{WP}$ was most efficacious and resulted in lowest mean disease incidence and intensity of 27.00 and 11.63 per cent, mean neck blast incidence of 8.35 per cent and a grain yield of $36.50 \mathrm{qha}^{-1}$. Tricyclazole $45 \%$ + hexaconazole $10 \mathrm{WG}$ was next in efficacy with mean disease incidence and intensity of $32.41,14.34$ per cent while mean neck blast incidence and grain yield 
were 11.62 per cent and $35.10 \mathrm{qha}^{-1}$, respectively. Tricyclazole $18 \%+$ mancozeb 62\%; mancozeb 63\% WP + carbendazim $12 \%$ WP carbendazim $50 \mathrm{WP}$ and hexaconazole 5 EC resulted in mean disease incidence of $35.62,36.91,37.75$ and 47.79 per cent; mean disease intensity of 16.62, 20.11, 23.45 and 29.06 per cent while neck blast incidence was $14.35,17.37,19.62$ and 21.80 per cent with a consequent grain yield of $34.00,33.20,32.75$ and $30.20 \mathrm{qha}^{-1}$, respectively. Mancozeb 75 WP was least efficacious among the fungicides tested and resulted in highest mean disease incidence and intensity of 56.12 and 41.01 per cent while neck blast incidence was 25.55 per cent and grain yield was $28.25 \mathrm{qha}^{-1}$, respectively. However it was significantly superior to the untreated control where mean disease incidence and intensity was 91.12 and 57.40 per cent while mean neck blast incidence was 35.55 per cent and grain yield was $21.75 \mathrm{qha}^{-1}$, respectively. The two years of experimentation indicted that overall disease incidence $(46.52 \%)$ and intensity (27.69\%) was higher during kharif 2015 than in kharif 2016 where it was 44.54 and 25.71 per cent, respectively. Similar trend was recorded in neck blast incidence. During kharif 2015 an overall higher neck blast incidence of 20.25 per cent was recorded while in kharif 2016, it was 18.30 per cent only. The higher disease in kharif 2015 as compared to kharif 2016 can be attributed to comparatively higher rainfall which resulted in more congenial conditions for disease development (Table 2).

Figure 1 depicts mean disease incidence and intensity as influenced by different fungicides during two years of experimentation. It is evident from the figure that tricyclazole 75 WP was most effective in reducing mean disease incidence and intensity while mancozeb 75 WP was least efficacious among the tested fungicides. Figure 2 reveals the mean neck blast incidence and grain yield as influenced by different fungicides recorded during two years of experimentation and indicate that tricyclazole $75 \mathrm{WP}$ was also most efficacious in reducing the mean neck blast incidence and increasing the grain yield.

In present investigations tricyclazole $75 \mathrm{WP}$ was found most efficacious fungicide in checking the rice blast disease and increasing the grain yield which is in conformity with the findings of Sood and Kapoor (1997), Srivastava (1999) and Dubey (2000). The efficacy of other fungitoxicants against rice blast has also been reported by various workers (Dubey, 2000; Sharma and Kapoor, 2002; Hedge et al., 2002; Ganesh et al., 2012).

Table.1 Scale used for rating of rice blast disease

\begin{tabular}{|l|l|}
\hline Score & Description \\
\hline $\mathbf{0}$ & No lesion observed \\
\hline $\mathbf{1}$ & small brown specks of pin head size \\
\hline $\mathbf{2}$ & $\begin{array}{l}\text { Small roundish to slightly elongated necrotic grey spots about } 1 \text { to } 2 \mathrm{~mm} \text { in diameter witl } \\
\text { distinct brown margin. Lesions are mostly found on the lower leaves }\end{array}$ \\
\hline $\mathbf{3}$ & Lesion same type as in 2 but significant on the upper leaves \\
\hline $\mathbf{4}$ & Typical susceptible blast lesions, 3mm or longer infecting less than $4 \%$ of leaf area \\
\hline $\mathbf{5}$ & Typical susceptible blast lesions, 3mm or longer infecting 4-10\% of leaf area \\
\hline $\mathbf{6}$ & Typical susceptible blast lesions of 3mm or longer infecting 11- 25\% of the leaf area \\
\hline $\mathbf{7}$ & Typical susceptible blast lesions of 3mm or longer infecting 26-50\% of the leaf area \\
\hline $\mathbf{8}$ & Typical susceptible blast lesions of 3mm or longer infecting 51-75\% of the leaf area \\
\hline $\mathbf{9}$ & Typical susceptible blast lesions of 3mm or longer infecting more than75\% of the leaf area \\
\hline
\end{tabular}


Table.2 Bio-efficacy of foliar sprays of some fungicides against rice blast (Pyricularia grisea) on rice cv. Kamad

\begin{tabular}{|c|c|c|c|c|c|c|c|c|c|c|c|c|c|}
\hline \multirow[t]{2}{*}{ Fungitoxicant } & \multirow[t]{2}{*}{$\begin{array}{l}\text { Conc. } \\
(\%)\end{array}$} & \multicolumn{2}{|c|}{ Disease incidence $(\%)$} & \multirow[t]{2}{*}{ Mean } & \multicolumn{2}{|c|}{$\begin{array}{c}\text { Disease intensity } \\
(\%)\end{array}$} & \multirow[t]{2}{*}{ Mean } & \multicolumn{2}{|c|}{$\begin{array}{c}\text { Neck blast } \\
\text { incidence }(\%)\end{array}$} & \multirow[t]{2}{*}{ Mean } & \multicolumn{2}{|c|}{$\begin{array}{l}\text { Grain Yield } \\
\text { qha }^{-1}\end{array}$} & \multirow[t]{2}{*}{ Mean } \\
\hline & & I $^{\text {st }}$ year & $2^{\text {nd }}$ year & & $I^{\text {st }}$ year & $2^{\text {nd }}$ year & & $I^{\text {st }}$ year & $2^{\text {nd }}$ year & & $I^{\text {st }}$ year & $2^{\text {nd }}$ year & \\
\hline $\begin{array}{l}\text { Tricyclazole } 45 \% \\
\text { + hexaconazole } 10 \\
\text { WG }\end{array}$ & 0.1 & $\begin{array}{l}33.33 \\
(35.26)\end{array}$ & $\begin{array}{l}31.50 \\
(34.13)\end{array}$ & 32.41 & $\begin{array}{c}14.73 \\
(22.56)\end{array}$ & $\begin{array}{l}13.95 \\
(21.92)\end{array}$ & 14.34 & $\begin{array}{l}12.50 \\
(20.70)\end{array}$ & $\begin{array}{l}10.75 \\
(19.13)\end{array}$ & 11.62 & $\begin{array}{l}34.50 \\
(35.96)\end{array}$ & $\begin{array}{l}35.70 \\
(36.68)\end{array}$ & 35.10 \\
\hline $\begin{array}{l}\text { Tricyclazole } 18 \% \\
+ \text { mancozeb } 62 \%\end{array}$ & 0.25 & $\begin{array}{l}35.75 \\
(36.72)\end{array}$ & $\begin{array}{l}34.50 \\
(35.96)\end{array}$ & 35.62 & $\begin{array}{c}17.38 \\
(24.63)\end{array}$ & $\begin{array}{l}15.87 \\
(23.47)\end{array}$ & 16.62 & $\begin{array}{l}15.25 \\
(22.98)\end{array}$ & $\begin{array}{l}13.45 \\
(21.51)\end{array}$ & 14.35 & $\begin{array}{l}33.75 \\
(35.51)\end{array}$ & $\begin{array}{l}34.25 \\
(35.81)\end{array}$ & 34.00 \\
\hline $\begin{array}{l}\text { Tricyclazole } \\
\text { WP }\end{array}$ & 0.06 & $\begin{array}{l}28.50 \\
(32.26)\end{array}$ & $\begin{array}{l}25.50 \\
(30.32)\end{array}$ & 27.00 & $\begin{array}{c}12.95 \\
(21.08)\end{array}$ & $\begin{array}{l}10.31 \\
(18.72)\end{array}$ & 11.63 & $\begin{array}{l}9.45 \\
(17.90)\end{array}$ & $\begin{array}{l}7.25 \\
(15.61)\end{array}$ & 8.35 & $\begin{array}{l}36.00 \\
(36.86)\end{array}$ & $\begin{array}{l}37.00 \\
(37.46)\end{array}$ & 36.50 \\
\hline $\begin{array}{l}\text { Hexaconazole } 5 \\
\text { EC }\end{array}$ & 0.05 & $\begin{array}{l}48.25 \\
(43.99)\end{array}$ & $\begin{array}{l}47.33 \\
(43.46)\end{array}$ & 47.79 & $\begin{array}{c}29.77 \\
(33.06)\end{array}$ & $\begin{array}{l}28.35 \\
(32.16)\end{array}$ & 29.06 & $\begin{array}{l}23.15 \\
(28.75)\end{array}$ & $\begin{array}{l}20.45 \\
(26.88)\end{array}$ & 21.80 & $\begin{array}{l}29.70 \\
(33.01)\end{array}$ & $\begin{array}{l}30.70 \\
(33.64\end{array}$ & 30.20 \\
\hline Mancozeb 75 WP & 0.03 & $\begin{array}{l}56.75 \\
(48.87)\end{array}$ & $\begin{array}{l}55.50 \\
(48.15)\end{array}$ & 56.12 & $\begin{array}{c}42.67 \\
(40.78)\end{array}$ & $\begin{array}{l}39.35 \\
(38.84)\end{array}$ & 41.01 & $\begin{array}{l}26.35 \\
(30.88)\end{array}$ & $\begin{array}{l}24.75 \\
(29.83)\end{array}$ & 25.55 & $\begin{array}{l}27.10 \\
(31.36)\end{array}$ & $\begin{array}{l}29.40 \\
(32.83)\end{array}$ & 28.25 \\
\hline $\begin{array}{l}\text { Mancozeb 63\% } \\
\text { WP + } \\
\text { carbendazim12\% } \\
\text { WP }\end{array}$ & 0.15 & $\begin{array}{l}38.33 \\
(38.25)\end{array}$ & $\begin{array}{l}35.50 \\
(36.56)\end{array}$ & 36.91 & $\begin{array}{l}21.225 \\
(27.42)\end{array}$ & $\begin{array}{l}18.97 \\
(25.81)\end{array}$ & 20.11 & $\begin{array}{l}18.50 \\
(25.47)\end{array}$ & $\begin{array}{l}16.25 \\
(23.77)\end{array}$ & 17.37 & $\begin{array}{l}32.25 \\
(34.59)\end{array}$ & $\begin{array}{l}34.15 \\
(35.75)\end{array}$ & 33.20 \\
\hline $\begin{array}{l}\text { Carbendazim } 50 \\
\text { WP }\end{array}$ & 0.1 & $\begin{array}{l}38.75 \\
(387.49)\end{array}$ & $\begin{array}{l}36.75 \\
(37.31)\end{array}$ & 37.75 & $\begin{array}{l}24.37 \\
(29.57)\end{array}$ & $\begin{array}{l}22.57 \\
(28.36)\end{array}$ & 23.45 & $\begin{array}{l}20.50 \\
(26.91)\end{array}$ & $\begin{array}{l}18.75 \\
(25.65)\end{array}$ & 19.62 & $\begin{array}{l}31.90 \\
(34.38)\end{array}$ & $\begin{array}{l}33.60 \\
(35.42)\end{array}$ & 32.75 \\
\hline \multirow[t]{2}{*}{ Control } & - & $\begin{array}{l}92.50 \\
(74.10)\end{array}$ & $\begin{array}{l}89.75 \\
(71.32)\end{array}$ & 91.12 & $\begin{array}{l}58.43 \\
(49.84)\end{array}$ & $\begin{array}{l}56.37 \\
(48.65)\end{array}$ & $\mathbf{5 7 . 4 0}$ & $\begin{array}{l}36.35 \\
(37.07)\end{array}$ & $\begin{array}{l}34.75 \\
(36.11)\end{array}$ & 35.55 & $\begin{array}{l}20.90 \\
(27.20)\end{array}$ & $\begin{array}{l}22.60 \\
(28.38)\end{array}$ & 21.75 \\
\hline & $\mathrm{CD}(\mathrm{p}=0.05)$ & $(2.20)$ & 2.15 & & 1.74 & 1.68 & & 1.27 & 1.22 & & 0.77 & 0.72 & \\
\hline
\end{tabular}

* Figures in parenthesis are arc sin transformed values 
Int.J.Curr.Microbiol.App.Sci (2018) 7(7): 3511-3516

Fig. 1 Effect of fungicides on rice blast incidence and intensity
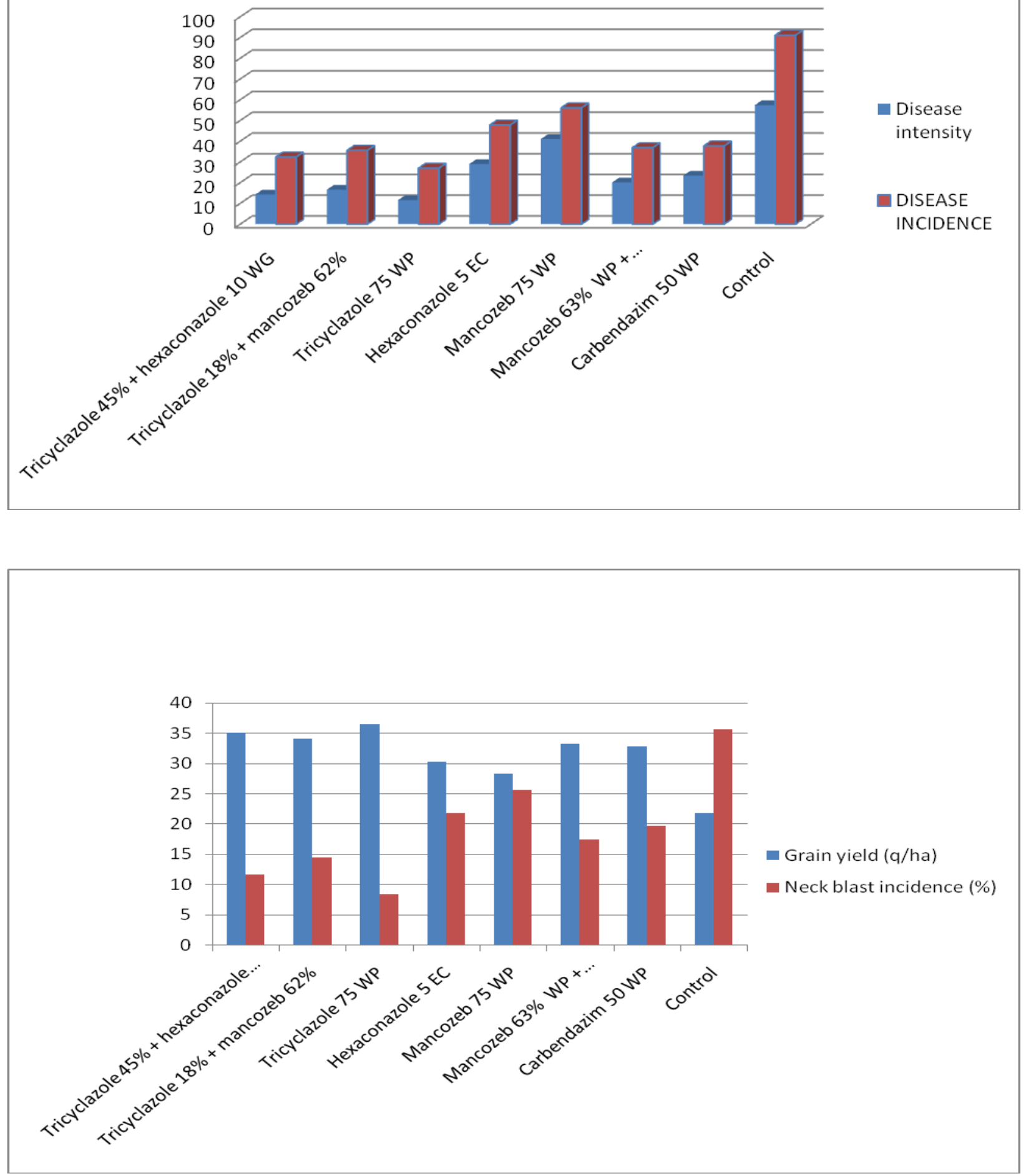
It is always desirable to use resistant genotypes for safe crop production and ecological concerns but some local cultivars which are popular for their taste and aroma lack the genes for resistance and therefore are vulnerable for diseases. It therefore, becomes imperative to use fungicides for management of diseases before the molecular work of incorporation of resistant genes is taken up by Scientists. The present investigations have revealed that in addition to the popular fungicide tricyclazole $75 \mathrm{WP}$, there are other effective new combination fungicides like tricyclazole $45 \%$ + hexaconazole $10 \mathrm{WG}$, tricyclazole $18 \%+$ mancozeb $62 \%$ and mancozeb $63 \% \mathrm{WP}+$ carbendazim $12 \% \mathrm{WP}$ which can be used as alternative or additional fungicides for management of rice blast as there is always risk of development of resistance if a single fungicide (tricyclazole $75 \mathrm{WP}$ ) is used repeatedly.

\section{References}

Anonymous, 2016. Digest of Statistics. Directorate of economics And Statistics, Govt. of Jammu and Kash

Dubey, S.C. 2000. Economical spray schedule of fungicides for blast management in rice. Plant disease Research 15(1): 43 45

Eizenga, G.C., Lee, F.N. and Rutger, J.N., 2002. Screening Oryza species plants for rice sheath blight resistance. Plant Disease 66: 808-812.

Ganesh Naik R, Gangadhara NaiK B., Basavaraja Naik $\mathrm{T}$ and Krishna Naik R. 2012. Fungicidal management of leaf blast disease in rice. Global journal of Bio-Sciences and Biotechnology. 2012: 18-21.

Hedge, Y., palakshappa, M.S., kalappanavar, I.K., Mohankumar, H.D., Angadi, V.V. 2000. Karnataka Journal of Agricultiral Sciences. 13(2): 372-375.

IRRI. 1996. Standard evaluation system for rice. $4^{\text {th }}$ Ed. IRRI, Manila, Philippines

Mohammad Najeeb Mughal, Sabiya Bashir and AliAnwar 2016. Comparative efficacy of botanical extracts against rice sheath blight (Thanatephorus cucumeris). New Agriculturist 27(1): 63-69

Mohd Najeeb, Sabiya Bashir and C.S Kalha 2006. Race identification of Pyricularia grisea. Annals of Plant Protection Sciences 14(2):499-501

Sood, G.L. and Kapoor, A.S. 1997. Effect of new fungicide in the management of rice blast Plant Disease Research. 2:140-142

Srivastava L.S.1999. management of rice blast through fungitoxicants in Sikkim. Journal of Hill research 12 (12): 164-165. Sharma and Kapoor, A. S. 2002. Management of rice blast (Pyricularia grisea) through host resistance and chemicals in hills. Plant disease Research 17(20: 283-290

Vihol J.B, Patel K. D, Jaiman R. K and Patel N.R. 2009. Efficacy of plant extracts, biological control agents and fungicides against Alternaria blight of cumin. Journal of Mycology and Plant Pathology 39(3):516-519.

\section{How to cite this article:}

Mohammad Najeeb Mughal, Sabiya Bashir, N.A. Sofi and Shabir Ahmed Wani. 2018. Bioefficacy of some Fungicides against Rice Blast (Pyricularia grisea) under Temperate Agroclimatic Conditions of Kashmir. Int.J.Curr.Microbiol.App.Sci. 7(07): 3511-3516. doi: https://doi.org/10.20546/ijcmas.2018.707.407 